\title{
Interplacental uterine expression of genes involved in prostaglandin synthesis during canine pregnancy and at induced prepartum luteolysis/abortion
}

\author{
Mariusz P Kowalewski ${ }^{*}$, Ewa Kautz ${ }^{1}$, Elisabeth Högger ${ }^{1}$, Bernd Hoffmann ${ }^{2}$ and Alois Boos ${ }^{1}$
}

\begin{abstract}
Background: In the non-pregnant dog, ovarian cyclicity is independent of a uterine luteolysin. This is in contrast to pregnant animals where a prepartum increase of luteolytic PGF2a occurs, apparently originating in the pregnant uterus. Recently, the placenta as a source of prepartum prostaglandins (PGs) was investigated, indicating fetal trophoblast cells as the likely main source. However, the possible contribution of uterine interplacental tissues to the production of these hormones has not yet been thoroughly examined in the dog.

Methods: Several key factors involved in the production and/or actions of PGs were studied: cyclooxygenase 2 (COX2, PTGS2), PGF2a-synthase (PGFS/AKR1C3), PGE2-synthase (PGES), and the respective receptors FP (PTGFR), EP2 (PTGER2) and EP4 (PGTER4), 15-hydroxyprostaglandin dehydrogenase (HPGD), PG-transporter (PGT, SLCO2A1) and progesterone receptor. Their expression and localization patterns were assessed by Real Time PCR and immunohistology in the interplacental uterine sites from pregnant dogs during the pre-implantation period (days 8-12), post-implantation (days 18-25), mid-gestation (days 35-40) and during antigestagen-induced luteolysis/abortion.

Results: Whereas only low COX2 expression was observed in uterine samples at all the selected time points, expression of PGFS/AKR1C3 strongly increased post-implantation. A gradual increase in PGES-mRNA expression was noted towards mid-gestation. FP-mRNA expression decreased significantly with the progression of pregnancy until mid-gestation. This was associated with clearly detectable expression of HPGD, which did not change significantly over time. The expression of FP and EP2-mRNA decreased significantly over time while EP4-mRNA expression remained unaffected. The antigestagen-treatment led to a significant increase in expression of COX2, PGES, EP2 and PGT (SLCO2A1) mRNA. COX2 was localized predominantly in the myometrium. The expression of PGFS/AKR1C3, which was unchanged, was localized mostly to the surface luminal epithelium. The expression of EP4, PGT and HPGH did not change during treatment, they were co-localized with PGES and EP2 in all uterine compartments.
\end{abstract}

Conclusions: The data clearly demonstrate the basic capability of the canine pregnant uterus to produce and respond to PGs and suggests their functions both as local regulatory factors involved in the establishment and maintenance of pregnancy, as well as potential contributors to the process of parturition, supporting the myometrial contractility associated with fetal expulsion.

Keywords: Canine uterus, Prostaglandins

\footnotetext{
* Correspondence: kowalewski@vetanat.uzh.ch

${ }^{1}$ Institute of Veterinary Anatomy, Vetsuisse Faculty, University of Zurich,

Zurich, Switzerland

Full list of author information is available at the end of the article
}

\section{Biomed Central}

(c) 2014 Kowalewski et al.; licensee BioMed Central Ltd. This is an Open Access article distributed under the terms of the Creative Commons Attribution License (http://creativecommons.org/licenses/by/4.0), which permits unrestricted use, distribution, and reproduction in any medium, provided the original work is properly credited. The Creative Commons Public Domain Dedication waiver (http://creativecommons.org/publicdomain/zero/1.0/) applies to the data made available in this article, unless otherwise stated. 


\section{Background}

In the domestic dog (Canis familiaris), the establishment and maintenance of pregnancy depend on the luteal provision of progesterone (P4) as the only source of this hormone both during gestation and in the non-pregnant cycle [1,2]. Luteal function is similar in both pregnant and non-pregnant bitches (see reviews in [3-5]). The circulating P4 levels start to deviate strongly only shortly prior to term on days $62 / 63$, when a steep decline marks onset of prepartum luteolysis 12-24 h before the first clinical signs of labour become visible [6,7]. In nonpregnant animals, in contrast, luteal regression continues beyond this point of time and circulating P4 concentrations decrease slowly until levels below $1 \mathrm{ng} / \mathrm{ml}$ are reached about 10 to 20 days later and the cycle enters the phase of obligatory sexual quiescence, i.e., anoestrus [6]. Consequently, in contrast to what is observed in non-pregnant dogs, prepartum luteolysis appears to be a process governed by active regulatory mechanisms. In respect to luteolytic factors, normal cyclic ovarian steroidogenic function has been observed in hysterectomized bitches, as in cats and primates, rendering luteal function as independent of a uterine luteolysin (prostaglandin (PG) F2 $\alpha$; PGF $2 \alpha$ ) in these species $[8,9]$. This is in contrast to livestock, where ovarian cyclicity is maintained due to periodic production and secretion of uterine PGF2 $\alpha$.

In dogs, prostaglandins synthesized locally within the corpus luteum appear to be involved in luteal maintenance rather than in luteolysis/regression, as indicated by increased expression of cyclooxygenase 2 (COX2, PTGS2) and PGE2-synthase (PGES) at the beginning of the canine luteal phase [10-12]. This hypothesis has been substantiated recently by showing a luteotrophic role of PGE2 in canine lutein cells in vitro. Acting mostly at the level of substrate provision facilitated by steroidogenic acute regulatory (STAR) protein expression and function, and not at the level of activity of the two major steroidogenic enzymes, 3ßHSD and P450scc enzyme, PGE2 significantly increased progesterone output in lutein cells [13].

In pregnant animals the prepartum luteolysis is concomitant with a rapid increase of PGF $2 \alpha$ in maternal peripheral blood, implying its involvement during prepartum luteolysis and/or fetal expulsion [14-16]. With regard to the endocrine mechanisms regulating the process of parturition in the dog, most of the currently available knowledge relates to the endocrine capabilities of the utero-placental compartments, comprising the placenta with its adjacent uterine tissues [15,17-20]. Recent investigations into the expression of factors involved in prostaglandin synthesis and function, the so-called PG-system, have indicated an upregulated expression of COX2 in fetal trophoblast cells as the possible origin of prepartum PGF $2 \alpha$ release within the utero-placental compartment [15]. This finding corroborates the observation from the same study that interfering with P4 receptor (PGR) function by application of an antigestagen in mid-pregnant dogs leads to upregulation of utero-placental COX2 expression, mostly in the fetal trophoblast, and results in significantly elevated peripheral PGF2 $\alpha$ concentrations. The only known canine-specific PGF2 $\alpha$-synthase (PGFS), classified as aldo-keto reductase family 1, member C3 (AKR1C3) which is responsible for the direct conversion of PGH2 to PGF2 $\alpha$, was localized in epithelial cells of the superficial uterine glands, the so-called glandular chambers, and in fetal trophoblasts [17]. Interestingly, however, expression of this enzyme was decreased during prepartum luteolysis. This was paralleled by the reduced expression of 15-hydroxyprostaglandin dehydrogenase (HPGD), an enzyme catabolising PGF2 $\alpha$ and PGE2 to their inactive metabolites [17]. Together with the concomitantly increased expression of PGE2-synthase (PGES) [15], a possible functional interrelationship between these entities has been suggested. The potential involvement of alternative pathways for PGF2 $\alpha$ synthesis has not, however, yet been investigated. It is noteworthy that the results to date clearly show that there is no parturition-related increase in estrogens mediating the prepartum PGF $2 \alpha$ release, and the sporadically observed elevated levels of cortisol measured in maternal blood peripartum seem not to be mandatory for normal canine parturition $[1,21]$.

Less attention has been paid so far to uterine endocrine capabilities in the dog during pregnancy and parturition, especially those uterine sites not attached to the placenta. In one study, basal and 12,13-phorbol dibutyrate (PDBu; protein kinase $\mathrm{C}$ stimulator) - mediated capabilities of canine endometrial and placental explants to produce PGF2 $\alpha$ were determined in vitro, revealing that the endometrium of pregnant dogs seems to acquire an increased capacity to produce PGF $2 \alpha$ immediately prepartum, which - on a tissue weight basis of the explants used - exceeded even that of the placenta [20]. However, when taking into account the larger mass of placental tissue in vivo, the authors inferred that also the placenta might substantially contribute to the prepartum PGF2 $\alpha$ release. The latter conclusion was confirmed in own studies [15] which showed an upregulation of COX2 on the mRNA and protein level in the trophoblast prior to parturition, rather indicating that the placenta and not the endometrium is the main source of the prepartum PGF2 $\alpha$ release. Thus, the question regarding the involvement of prostaglandins synthesized in the interplacental sites in regulating the processes of pregnancy and parturition in the bitch is still open. Such a functional interrelationship has previously been established for other species, e.g., cattle, where increased uterine, intercaruncular expression of COX2 and PGF2 $\alpha$-receptor (PTGFR, FP) was observed in animals with induced parturition, indicating the likely contribution of this increase to labour [22]. 
Therefore, with the aim of improving our understanding of uterine endocrine function during canine gestation, here, the expression and localization of factors involved in prostaglandin synthesis and its biological activity, as well as the expression of progesterone receptor (PGR), were investigated in the interplacental uterine sites. Based on the tissue material available, gestational periods from the early pre-implantation stage until fully established pregnancy (mid-gestation) were included. Additionally, in order to investigate the possible functional pathways and aiming to gain further information on the underlying endocrine mechanisms, expression of the PG-system was assessed in mid-pregnant bitches in which PGR function was blocked with an antigestagen in order to induce preterm luteolysis/abortion.

\section{Methods}

\section{Animals and tissue material}

As already indicated in a previous study [15], in which tissue materials from the same animals were used, all experimental procedures were carried out in accordance with animal welfare legislation ((permit no. II 25.3-19c2015c GI 18/14 and VIG3-19c-20/15c GI 18,14 (Justus-Liebig University, Giessen) and permit no. Ankara 2006/06 (Faculty of Veterinary Medicine, University of Ankara)).

Clinically healthy, crossbreed bitches, aged 2-8 years had been assigned to the following groups during selected time points of pregnancy: pre-implantation (days 8-12, $\mathrm{n}=5$ ), post-implantation (days $18-25, \mathrm{n}=5$ ) and midgestation (days 35-40, $\mathrm{n}=5$ ); the time of mating (day 0 ) was set as two days after ovulation, which was assessed by measuring peripheral $\mathrm{P} 4$ concentrations $(5>\mathrm{ng} / \mathrm{ml})$ and by vaginal cytology. Following ovariohysterectomy tissue samples were collected from the utero-placental compartment (see in [15]) and the interplacental sites (full thickness of the uterine wall). The latter, together with the uterine samples collected from the pre-implantation stage of pregnancy, were used for the present study. Tissues were preserved for mRNA-analysis and immunohistochemistry as previously described [15]. The preimplantation stage of early pregnancy was confirmed by uterine flushing of embryos. Based on the temporal developmental characteristics of canine uterine and placental tissues, the post-implantation and mid-gestation groups used in our study relate to periods of canine pregnancy characterized according to the status of utero-placental units: either their early formation (post-implantation) or their full development (mid-gestation, around day 40 of gestation) [23,24].

Abortion was induced in ten dogs (days 40-45 of pregnancy) by application of the antigestagen Aglepristone ${ }^{\odot}$ [Alizine ${ }^{\bullet}$ Virbac, $10 \mathrm{mg} / \mathrm{Kg}$ bw $(2 \times / 24 \mathrm{hrs}$ apart)]; ovariohysterectomies were performed $24 \mathrm{hrs}(\mathrm{n}=5)$ and $72 \mathrm{hrs}$ $(\mathrm{n}=5)$ after the second treatment.

\section{Total RNA extraction, semi-quantitative RT-PCR}

TRIzol $^{\circledR}$ reagent (Invitrogen, Carlsbad, CA, USA) was used for total RNA isolation according to the manufacturer's instructions and the RNA content was measured with a NanoDrop 2000C ${ }^{\ominus}$ spectrophotometer (Thermo Fisher Scientific AG, Reinach, $\mathrm{CH}$ ). The elimination of genomic DNA contamination was achieved by DNase-treatment of all isolated RNAs with RQ1 RNase-free DNase (Promega, Dübendorf, $\mathrm{CH}$ ) following the manufacturer's protocol. The reverse transcriptase (RT) reaction was performed using random hexamers as primers and other reagents from Applied Biosystems (Foster City, CA, USA) as previously described [12,18]. For each RT reaction, 100 ng of DNase-treated total RNA were used. The reactions were carried out in an Eppendorf Mastercycler ${ }^{\odot}$ (Vaudaux-Eppendrf AG, Basel, CH) under the following experimental conditions: $8 \mathrm{~min}$ at $21^{\circ} \mathrm{C}$ and $15 \mathrm{~min}$ at $42^{\circ} \mathrm{C}$, then the reaction was stopped by incubation for $5 \mathrm{~min}$ at $99^{\circ} \mathrm{C}$.

An automated fluorometer ABI PRISM ${ }^{\circ} 7500$ Sequence Detection System (Applied Biosystems) was used for semi-quantitative Real Time (TaqMan) PCR according to our previously described protocol [12,18]. All samples were run in duplicate. Autoclaved water instead of cDNA and the so-called RT-minus control (samples that were not reverse transcribed) were used for negative controls. The following $25 \mu \mathrm{l}$ reaction mixtures were prepared containing: Fast Start Universal Probe Master Mix (ROX) ${ }^{\circ}$ (Roche Diagnostics, Rotkreuz, CH), 200 nM TaqMan Probe, $300 \mathrm{nM}$ of each primer, $12.5 \mu$ l Fast Start Universal Probe Master Mix (ROX), $5 \mu \mathrm{l}$ cDNA corresponding to $100 \mathrm{~nm}$ total RNA per sample. The cycling conditions were: denaturation at $95^{\circ} \mathrm{C}$ for $10 \mathrm{~min}, 40$ cycles at $95^{\circ} \mathrm{C}$ for $15 \mathrm{sec}$, and $60^{\circ} \mathrm{C}$ for $60 \mathrm{sec}$. The list of primers and TaqMan probes labelled with 6-carboxyfluorescein (6FAM) and 6-carboxytetramethyl-rhodamine (TAMRA) is presented in Table 1. All primers were designed using Primer Express Software (Version 2.0, Applied Biosystems) and purchased from Microsynth (Balgach, $\mathrm{CH}$ ). Three different reference genes were used for normalization: GAPDH, 18SrRNA and cyclophilin A. The comparative $C T$ method ( $\triangle \triangle C T$ method) was applied for calculating relative gene expression levels according to a previously described protocol $[12,18]$ and following the instructions of the manufacturer of the ABI PRISM ${ }^{\odot} 7500 \mathrm{Se}^{-}$ quence Detection System. The sample with the lowest concentration was used as a calibrator for calculating the relative expression of target genes in this procedure. The PCR reactions were set up to ensure approximately $100 \%$ efficiency of reactions. A commercially available TaqMan System (primer and probe mixture) of caninespecific cyclophilin $A$ (TaqMan system) was purchased from Applied Biosystems (Prod. No. Cf03986523- gH). Selected PCR products were commercially sequenced 
Table 1 List of primers and taqman probes used for semi-quantitative RT-PCR

\begin{tabular}{|c|c|c|c|}
\hline Primer & Accession numbers & Primer sequence & Product lenght (bp) \\
\hline GAPDH (forward) & AB028142 & 5'-GCT GCCAAATAT GACGACATC A-3' & $75 b p$ \\
\hline GAPDH (reverse) & & 5'-GTA GCC CAG GAT GCC TIT GAG-3' & \\
\hline GAPDH (TaqMan Probe) & & 5'-TCC CTC CGA TGC CTG CTT CAC TAC CTT-3' & \\
\hline 18SrRNA (forward) & FJ797658 & 5'-GTC GCT CGC TCC TCT CCT ACT-3' & $125 b p$ \\
\hline 18SrRNA (reverse) & & 5'-GGC TGA CCG GGT TGG TाT-3' & \\
\hline 18SrRNA (TaqMan Probe) & & 5'-ACA TGC CGA CGG GCG CTG AC-3' & \\
\hline PGR (forward) & NM_001003074 & 5'-CGA GTC ATT ACC TCA GAA GAT TTG TTT-3' & $113 b p$ \\
\hline PGR (reverse) & & 5'-CTT CCA TTG CCC TाT TAA AGA AGA-3' & \\
\hline PGR (TaqMan Probe) & & 5'-AAG CAT CAG GCT GTC ATT ATG GTG TCC TAA CTT-3' & \\
\hline COX2 (forward) & HQ110882 & 5'-GGA GCA TAA CAG AGT GTG TGA TGT G-3' & $87 \mathrm{bp}$ \\
\hline COX2 (reverse) & & 5'-AAG TAT TAG CCT GCT CGT CTG GAA T-3' & \\
\hline COX2 (TaqMan Probe) & & 5'-CGC TCA TCA TCC CAT TCT GGG TGC-3' & \\
\hline PGFS/AKR1C3 (forward) & NM_001012344 & 5'-AGG GCT TGC CAA GTC TAT TGG-3' & $74 \mathrm{bp}$ \\
\hline PGFS/AKR1C3 (reverse) & & 5'-GCC TTG GCT TGC TCA GGA T-3' & \\
\hline PGFS/AKR1C3 (TaqMan Probe) & & 5'-TCC AAC TाT AAC CGC AGG CAG CTG G-3' & \\
\hline PGES (forward) & NM_001122854 & 5'-GTC CTG GCG CTG GTG AGT-3' & $89 \mathrm{bp}$ \\
\hline PGES (reverse) & & 5'-ATG ACA GCC ACC ACG TAC ATC T-3' & \\
\hline PGES (TaqMan Probe) & & 5'-TCC CAG CCT TCC TGC TCT GCA GC-3' & \\
\hline PTGFR (FP) (forward) & NM_001048097 & 5'-ACC AGT CGA ACA TCC TाT GCA-3' & $86 \mathrm{bp}$ \\
\hline PTGFR (FP) (reverse) & & 5'-GGC CAT CAC ACT GCC TAG AAA-3' & \\
\hline PTGFR (FP) (TaqMan Probe) & & 5'-CAT GGT GTT CTC CGG TCT GTG CCC-3' & \\
\hline PTGER2 (forward) & AF075602 & 5'- CAC CCT GCT GCT GCT TCT C-3' & $78 \mathrm{bp}$ \\
\hline PTGER2 (reverse) & & 5'-CGG TGC ATG CGG ATG AG-3' & \\
\hline PTGER2 (TaqMan Probe) & & 5'-TGC TCG CCT GCA ACT TTC AGC GTC-3' & \\
\hline PTGER4 (forward) & NM_001003054 & 5'-AAA TCA GCA AAA ACC CAG ACT TG-3' & $96 \mathrm{bp}$ \\
\hline PTGER4 (reverse) & & 5'-GCA CGG TCT TCC GCA GAA -3' & \\
\hline PTGER4 (TaqMan Probe) & & 5'-ATCCGA ATT GCT GCT GTG AAC CCT ATC C-3' & \\
\hline PGT (forward) & NM_001011558 & 5'-TGC AGC ACT AGG AAT GCT GTT C-3' & $116 b p$ \\
\hline PGT (reverse) & & 5'-GGG CGC AGA GAA TCA TGG A-3' & \\
\hline PGT (TaqMan probe) & & 5'-TCT GCA AAC CAT TCC CCG CGT G-3' & \\
\hline HPGD (forward) & NM_001284477 & 5'-GGC AGC GAA TCT CAT GAA CAG-3' & $93 \mathrm{bp}$ \\
\hline HPGD (reverse) & & 5'-TCT TCT TTC TCA ATG GAT TCA AGGA-3' & \\
\hline HPGD (TaqMan Probe) & & 5'-TGA ATG CCA TाT GCC CAG GCT TTG-3' & \\
\hline
\end{tabular}

(Microsynth) in order to confirm the specificity of amplicons.

\section{Data evaluation}

A parametric one-way analysis of variance (ANOVA) was applied to test for an effect of the observational group on COX2 (PTGS2), PGT (SLCO2A1) and PGR mRNA expression levels. In the case of $\mathrm{P}<0.05$, posttests (Tukey-Kramer multiple comparison test) were performed. Due to the uneven distribution of the data obtained for uterine mRNA expression of PGFS/AKR1C3, PGES, FP (PTGFR), EP2 and EP4 (PTGER2 and PTGER4) and HPGD, the Kruskal-Wallis test (a nonparametric ANOVA) followed by Dunn's multiple comparison test were performed in the event of $\mathrm{P}<0.05$. In experiments assessing the expression of target genes after Aglepristone ${ }^{\odot}$ induced preterm luteolysis (abortion), Dunnett's multiple comparison test was performed. In the latter case, the results presented display the $n$-fold change in target gene mRNA-levels compared to their expression in mid-gestation, which was used as the non-treated control. GraphPad 3.06 (GraphPad Software, Inc., San Diego, California, USA) was used for all tests. Data are presented as the mean \pm standard deviation. 


\section{Immunohistochemistry}

Our standard immunohistochemistry (IHC) procedure was applied on formalin-fixed, paraffin-embedded sections following the protocol described previously [12,17,25]. The list of primary antibodies and isotype controls is presented in Table 2. Briefly: after deparaffinization in xylol, slides were rehydrated in a graded ethanol series and washed under running tap water for $5 \mathrm{~min}$. Antigen retrieval was performed in $10 \mathrm{mM}$ citrate buffer $\mathrm{pH} 6.0$ at room temperature for $5 \mathrm{~min}$ followed by microwave irradiation in an oven run at $560 \mathrm{~W}$ for $15 \mathrm{~min}$ and for $20 \mathrm{~min}$ at room temperature. Endogenous peroxidase activity was quenched by incubating the sections in $0.3 \%$ hydrogen peroxide in methanol for $30 \mathrm{~min}$. The nonspecific binding sites were blocked with either $10 \%$ horse serum or $10 \%$ normal goat serum, depending on the secondary antibody used in experiments. Thereafter, slides were overlaid with primary antibodies and incubated overnight at $4^{\circ} \mathrm{C}$. Two negative controls were performed: (a) omitting the primary antibody, and (b) antiserum-specific isotype controls at the same dilution and protein concentration as the primary antibody. The incubation with secondary antibodies was for $30 \mathrm{~min}$ at room temperature using 1:100 dilution. Following biotinylated secondary antibodies were used: horse anti mouse IgG BA-2000, goat anti-guinea pig IgG BA-7000, goat anti rabbit IgG BA-1000 and horse anti goat IgG BA-9500, all from Vector Laboratories Inc., Burlingame, CA 94010, USA. Signals were enhanced with the streptavidin-avidinperoxidase Vectastain ABC kit (Vector Laboratories), for $30 \mathrm{~min}$ at room temperature. Peroxidase activity was detected with the DAB substrate Kit according to the manufacturer's instructions (Dako North America, Inc., City, Country). Post-staining was done using hematoxylin, slides were mounted in Histokit (Assistant Osterode, Germany).

\section{Results}

Semi-quantitation of uterine gene expression from pre-implantation until mid-gestation

Expression profiles of COX2 (PTGS2), PGFS/AKR1C3, FP (PTGFR), PGES, the PGE2 receptors EP2 and EP4 (PTGER2 and PTGER4), HPGD, the prostaglandin transporter (PGT, SLCO2A1) and the progesterone receptor $(P G R)$ were assessed in uterine interplacental sites using semi-quantitative Real Time (TaqMan) RT-PCR.

Whereas the expression of COX2 was low and did not change from pre-implantation until mid-gestation

Table 2 List of primary antibodies and isotype controls used for immunohistochemistry

\begin{tabular}{|c|c|c|c|c|c|}
\hline Name/antigen & Clone & Company & Immunogen & Concentration & Species/type \\
\hline $\operatorname{cox} 2$ & clone 33 & $\begin{array}{l}\text { BD Pharmingen } \\
\text { Heidelberg Germany }\end{array}$ & anti-rat COX-2 lgG & $1: 100$ & $\begin{array}{l}\text { mouse } \\
\text { monoclonal }\end{array}$ \\
\hline PGT & (G-17) Sc-103085 & $\begin{array}{l}\text { Santa Cruz Biotechnology } \\
\text { CA, USA }\end{array}$ & IgG against human PGT & $1: 100$ & $\begin{array}{l}\text { goat } \\
\text { polyclonal }\end{array}$ \\
\hline PGFS/AKR1C3 & $\begin{array}{l}\text { custom made canine-specific } \\
\text { antibody (Gram et al., } 2013 \text { [17]) }\end{array}$ & $\begin{array}{l}\text { Eurogentec Seraing } \\
\text { Belgium }\end{array}$ & $\begin{array}{l}\text { IgG against canine-specific peptide } \\
\text { sequence DTLFATHPDYPFNDED, } \\
\text { C-terminal amino acids 309-324 }\end{array}$ & $1: 750$ & $\begin{array}{l}\text { guinea pig } \\
\text { polyclonal }\end{array}$ \\
\hline PGES & $\begin{array}{l}\text { custom made canine-specific } \\
\text { antibody (Kautz et al., } 2014 \text { [26]) }\end{array}$ & $\begin{array}{l}\text { Eurogentec Seraing } \\
\text { Belgium }\end{array}$ & $\begin{array}{l}\text { IgG against canine-specific peptide } \\
\text { sequence RSDQDVDRCLRAHRND, } \\
\text { C-terminal amino acids } 61-76\end{array}$ & $1: 300$ & $\begin{array}{l}\text { guinea pig } \\
\text { polyclonal }\end{array}$ \\
\hline HPGD & $\begin{array}{l}\text { custom made canine-specific } \\
\text { antibody (Gram et al., } 2013 \text { [17]) }\end{array}$ & $\begin{array}{l}\text { Eurogentec Seraing } \\
\text { Belgium }\end{array}$ & $\begin{array}{l}\text { IgG against canine-specific peptide } \\
\text { sequence HFQDYEITPFHAKTQ, } \\
\text { C-terminal amino acids 252-266 }\end{array}$ & $1: 750$ & $\begin{array}{l}\text { guinea pig } \\
\text { polyclonal }\end{array}$ \\
\hline EP2 & catalog no. 101770 & $\begin{array}{l}\text { Cayman Chemicals } \\
\text { MI, USA }\end{array}$ & $\begin{array}{l}\text { IgG against human EP2, C-terminal } \\
\text { amino acids } 335-358\end{array}$ & $1: 200$ & $\begin{array}{l}\text { rabbit } \\
\text { polyclonal }\end{array}$ \\
\hline EP4 & catalog no. 101775 & $\begin{array}{l}\text { Cayman Chemicals } \\
\text { MI, USA }\end{array}$ & $\begin{array}{l}\text { IgG against human EP4, C-terminal } \\
\text { amino acids } 459-488\end{array}$ & $1: 100$ & $\begin{array}{l}\text { rabbit } \\
\text { polyclonal }\end{array}$ \\
\hline Isotype control & $\lg G$ & $\begin{array}{l}\text { Vector Laboratories Inc., } \\
\text { Burlingame, CA, USA }\end{array}$ & - & $\begin{array}{l}\text { Same protein } \\
\text { concentration as } \\
\text { primary antibody }\end{array}$ & mouse \\
\hline Isotype control & $\lg G$ & $\begin{array}{l}\text { Vector Laboratories Inc., } \\
\text { Burlingame, CA, USA }\end{array}$ & - & $\begin{array}{l}\text { Same protein } \\
\text { concentration as } \\
\text { primary antibody }\end{array}$ & rabbit \\
\hline Isotype control & $\lg G$ & $\begin{array}{l}\text { Vector Laboratories Inc., } \\
\text { Burlingame, CA, USA }\end{array}$ & - & $\begin{array}{l}\text { Same protein } \\
\text { concentration as } \\
\text { primary antibody }\end{array}$ & goat \\
\hline Isotype control & $\lg G$ & $\begin{array}{l}\text { Vector Laboratories Inc., } \\
\text { Burlingame, CA, USA }\end{array}$ & - & $\begin{array}{l}\text { Same protein } \\
\text { concentration as } \\
\text { primary antibody }\end{array}$ & guinea pig \\
\hline
\end{tabular}


$(\mathrm{P}=0.92)$ (Figure $1 \mathrm{~A})$, the uterine expression of PGFS/ AKR1C3 was strongly modulated over time $(\mathrm{P}=0.0005)$, increasing significantly from the pre-implantation to the post-implantation stage $(\mathrm{P}<0.01)$ (Figure $1 \mathrm{C})$, with the apparent decrease towards mid-gestation being not significant $(\mathrm{P}>0.05)$. A significant effect of time $(\mathrm{P}<0.0001)$ was observed for the $F P$ receptor with values continuously decreasing from pre-implantation until mid-gestation
$(\mathrm{P}<0.01)$ (Figure 2A). There was a significant effect of time for PGES mRNA expression $(\mathrm{P}=0.03)$ (Figure 1E), which increased gradually throughout the observational period, reaching the highest mRNA levels at mid-gestation $(\mathrm{P}<0.01)$. Of the two PGE2 receptors, only the expression of EP2 (PTGER2) changed significantly over time $(\mathrm{P}=0.003)$, being significantly diminished at mid-gestation compared with pre-implantation (Figure $2 \mathrm{C}$ ). In contrast,

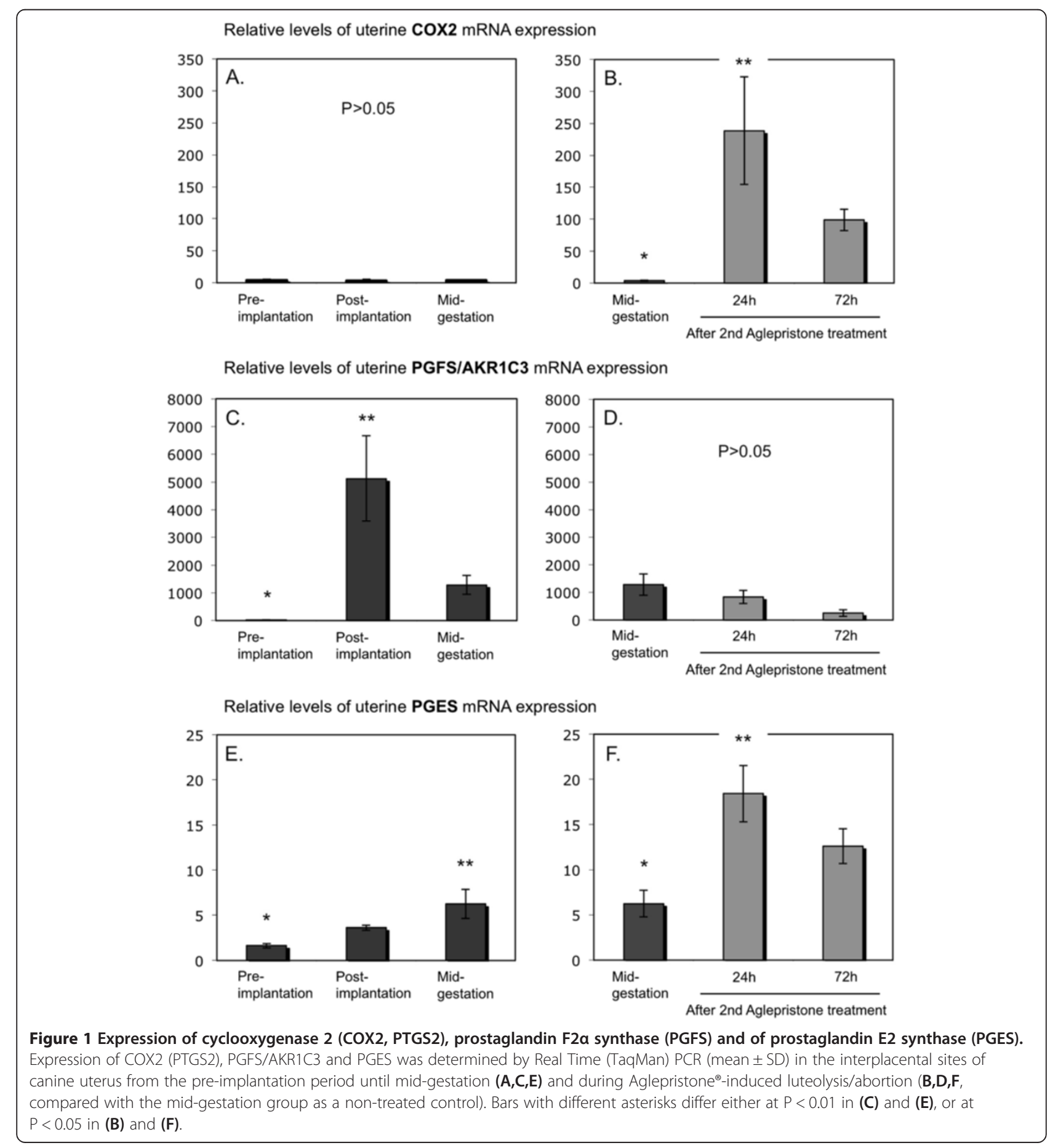



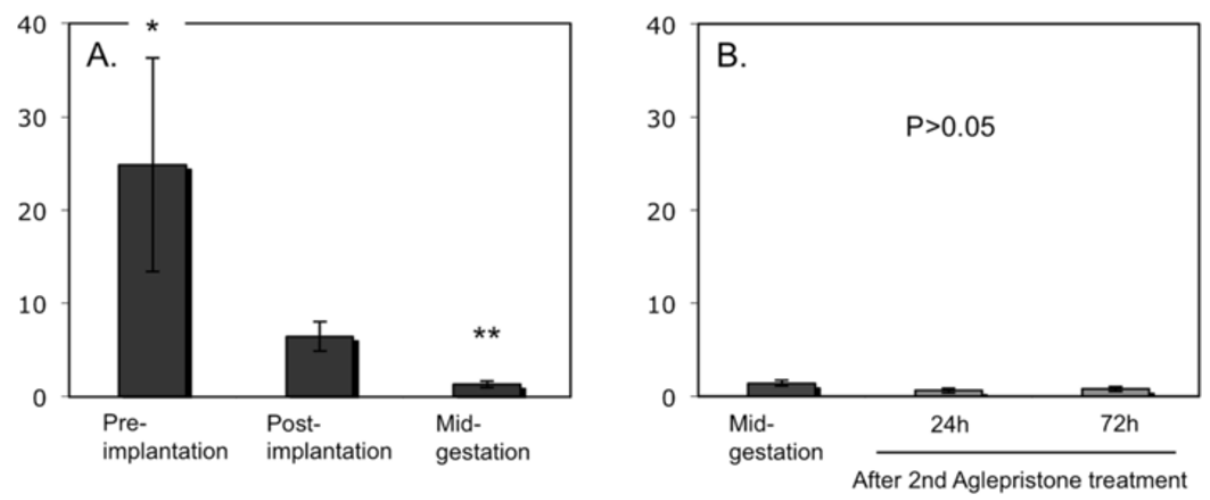

Relative levels of uterine EP2 mRNA expression
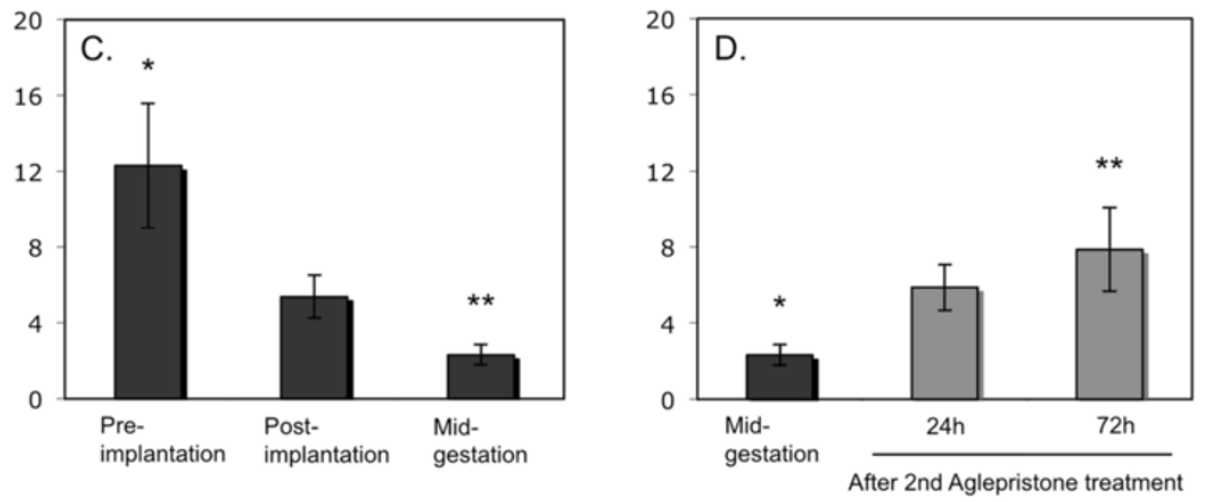

Relative levels of uterine EP4 mRNA expression
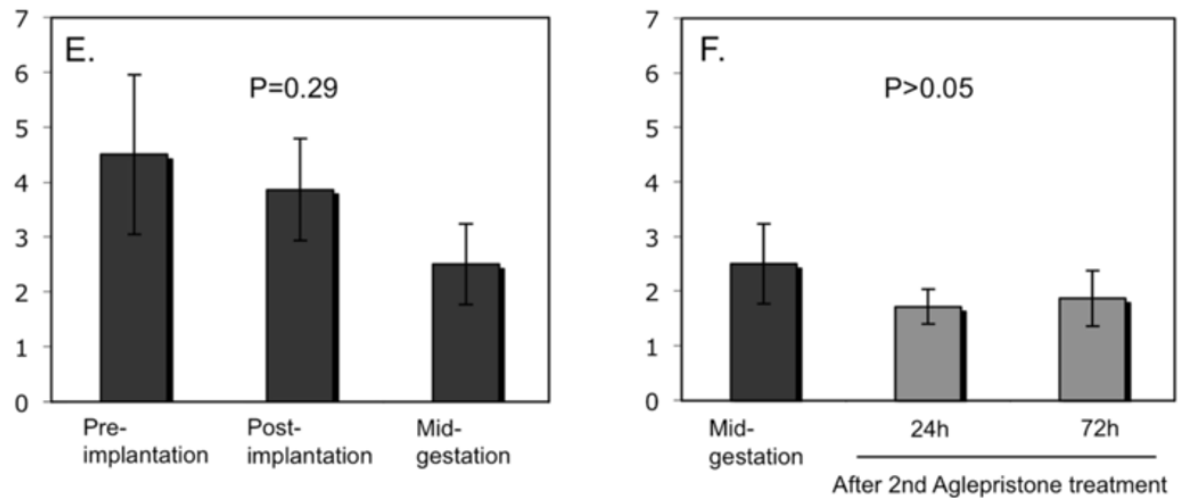

Figure 2 Expression of PGF2a receptor (FP, PTGFR) and of PGE2 receptors, EP2 (PTGER2) and EP4 (PTGER4). Expression of FP (PTGFR) and of EP2 and EP4 (PTGER2 and PTGER4, respectively) was determined by Real Time (TaqMan) PCR (mean \pm SD) in the interplacental sites of canine uterus from the pre-implantation period until mid-gestation $(\mathbf{A}, \mathbf{C}, \mathbf{E})$ and during Aglepristone ${ }^{\oplus}$-induced luteolysis/abortion $(\mathbf{B}, \mathbf{D}, \mathbf{F}, \mathbf{c o m p a r e d}$ with the mid-gestation group as non-treated control). Bars with different asterisks differ either at $\mathbf{P}<0.01$ in $(\mathbf{A})$ or at $\mathbf{P}<0.05$ in $(\mathbf{C}, \mathbf{D})$.

the expression of EP4 varied widely among samples and remained statistically unaffected $(\mathrm{P}=0.29)$ (Figure $2 \mathrm{E}$ ). The expression of PGT (SLCO2A1) was significantly altered throughout the observational period $(\mathrm{P}=0.01)$, increasing simultaneously with PGES mRNA and being higher in mid-pregnant dogs compared with the preimplantation stage $(\mathrm{P}<0.05)$ (Figure $3 \mathrm{~A})$. Although an apparent decrease was observed for HPGD mRNA expression with the progression of pregnancy, however, mostly because of very high variations in the specific mRNA content, the changes observed were statistically not significant $(P=0.13)$ (Figure $3 C$ ). As for PGR mRNA levels, after initially high expression during pre-implantation, they decreased afterwards, reaching significantly lower expression levels post-implantation and during mid-gestation $(\mathrm{P}<0.05)$ (Figure 3E). 


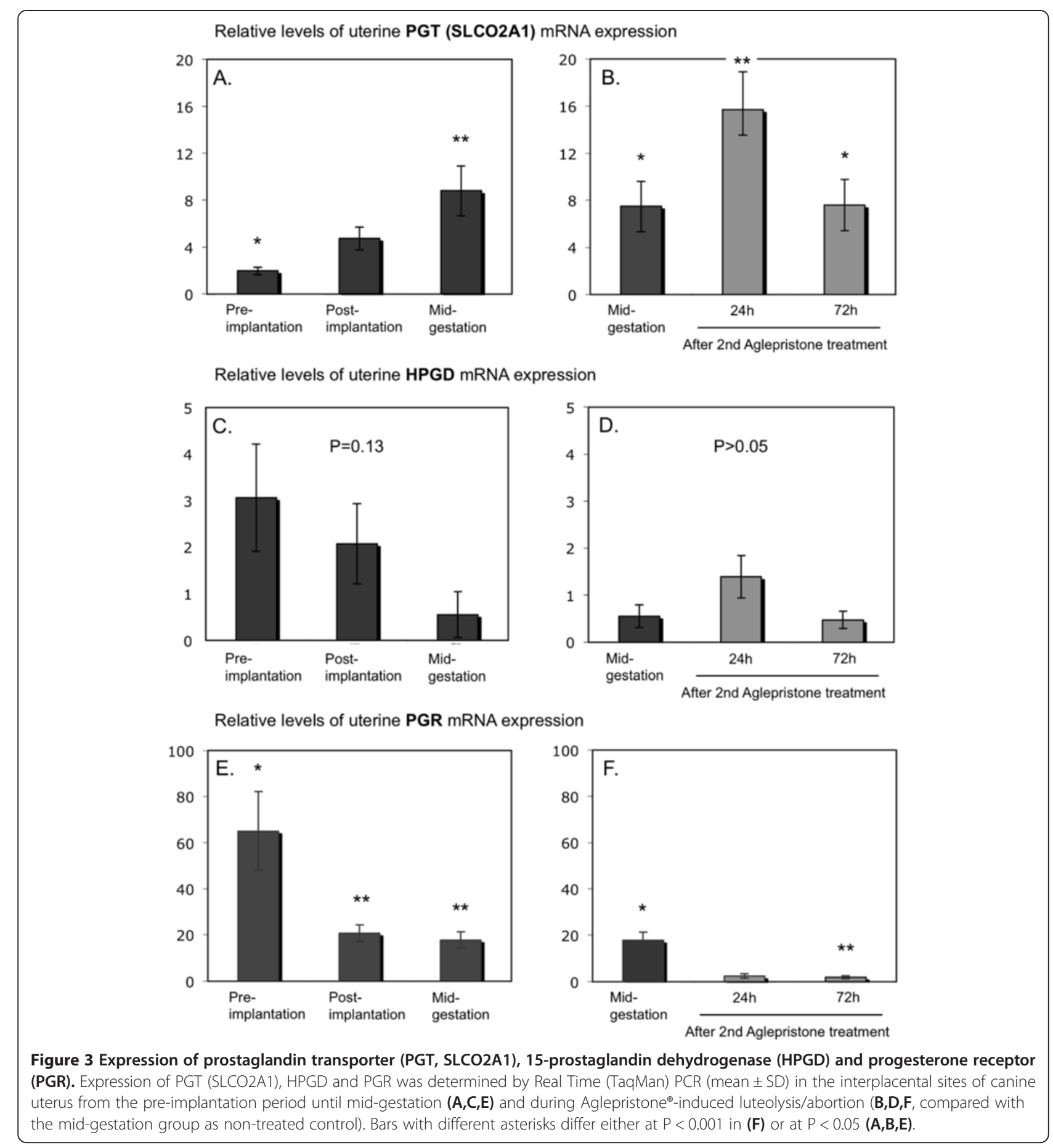

The effects of antiprogestin treatment on uterine gene expression

Uterine gene expression was assessed by semi-quantitative Real Time PCR in uteri obtained from antigestagentreated dogs. For all parameters, samples derived from the mid-gestation group served as non-treated controls in the statistical evaluation applying Dunnett's multiple comparison test. A significant increase in COX2 (PTGS2), PGES and PGT (SLCO2A1) expression was observed $24 \mathrm{hrs}$ after the second treatment with Aglepristone ${ }^{\oplus}(\mathrm{P}<0.05)$ (Figure $1 \mathrm{~B}$, Figure $1 \mathrm{~F}$ and Figure $3 \mathrm{~B}$ ). The increase in EP2 (PTGER2) levels was more pronounced $(\mathrm{P}<0.05)$ after $72 \mathrm{~h}$ (Figure 2D). An apparent suppression of PGR expression was already observed $24 \mathrm{~h}$ after the antigestagen treatment and it was significantly downregulated $(\mathrm{P}<0.001)$ at $72 \mathrm{~h}$ (Figure 3F). The expression of PGFS/AKR1C3, FP (PTGFR), 

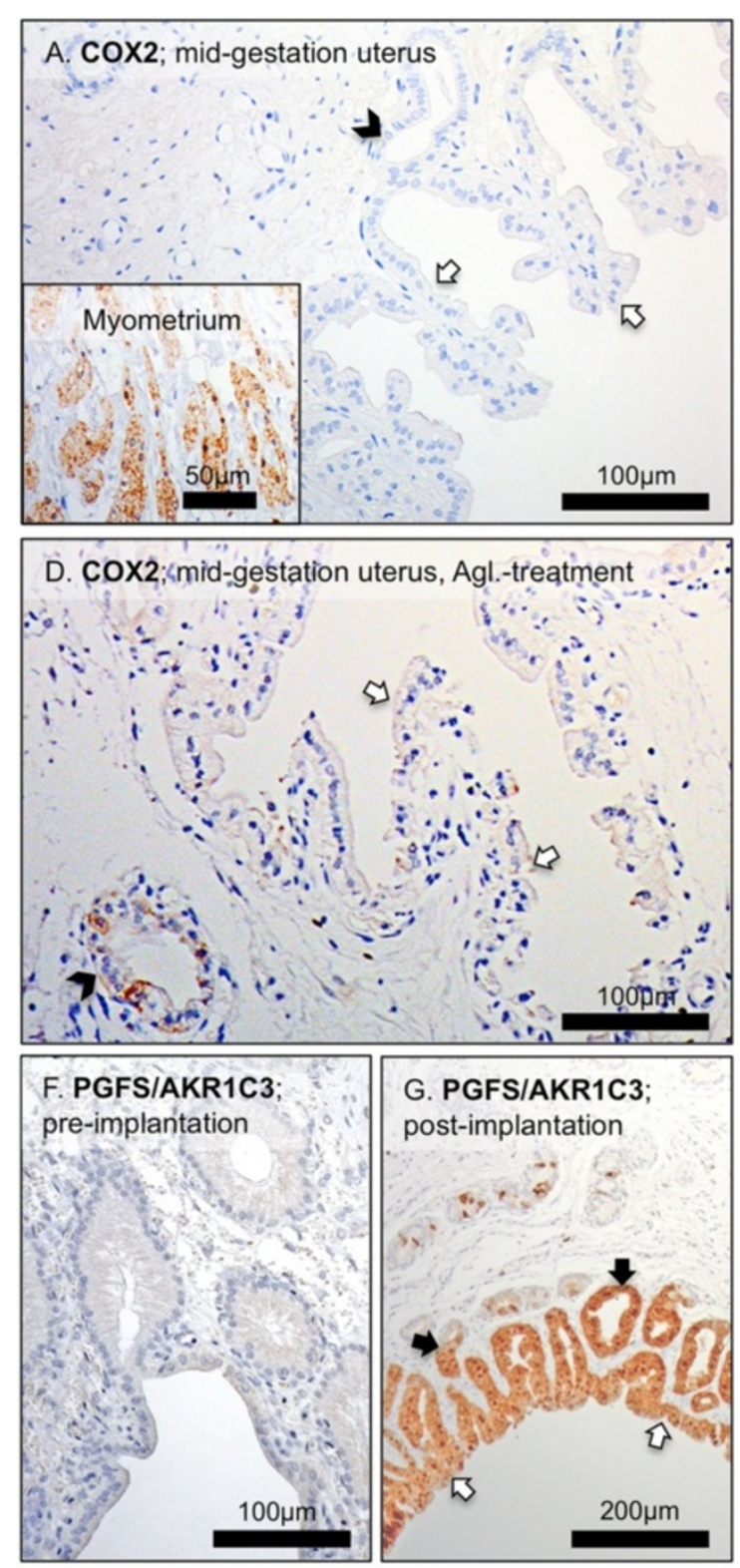

J. PGFS (AKR1C3); mid-gestation uterus, Agl.-treatment

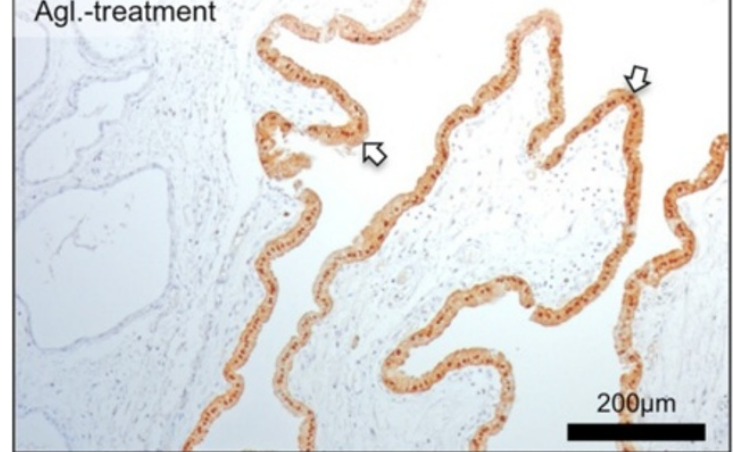

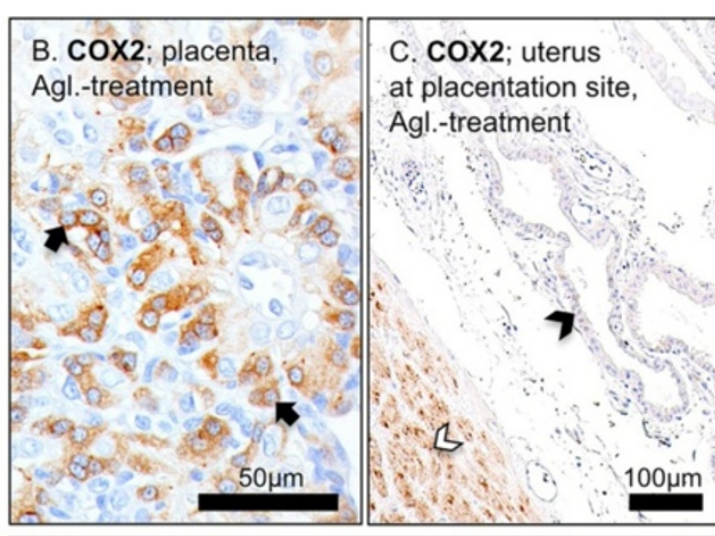

E. COX2; mid-gestation uterus, Agl--treatment
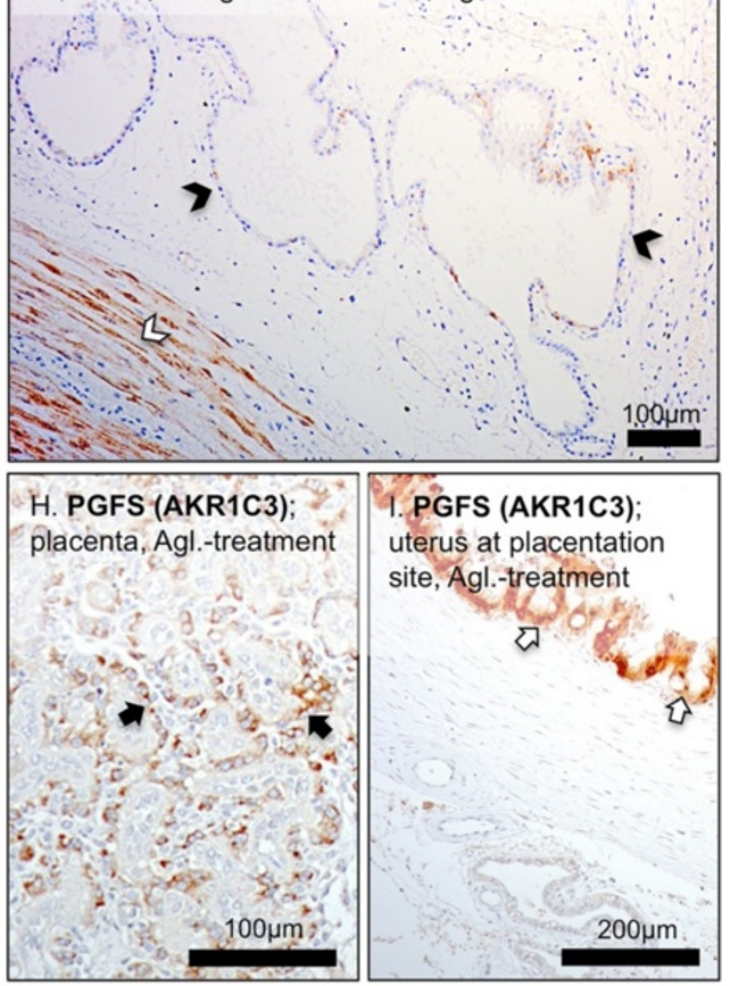

K. PGFS (AKR1C3); mid-gestation uterus, Agl.-treatment

ข 
(See figure on previous page.)

Figure 4 Immunohistochemical localization of cyclooxygenase 2 (COX2, PTGS2) and prostaglandin F2a synthase (PGFS/AKR1C3). Immunohistochemical (IHC) localization of COX2 (PTGS2) at interplacental uterine sites during mid-gestation (A), as well as in the utero-placental compartment $(\mathbf{B}, \mathbf{C})$, and interplacental uterine sites $(\mathbf{D}, \mathbf{E})$ during Aglepristone ${ }^{\circledR}$ (Agl.)-induced abortion. IHC localization of PGFS/AKR1C3 in the uterus pre-implantation (F), post-implantation $\mathbf{( G )}$ and in the utero-placental compartment $\mathbf{( H , I )}$ and interplacental uterine sites $\mathbf{( J , K )}$ during Aglepristone $^{\oplus}$ (Agl.)-induced abortion. Whereas no or only very weak COX2 IHC signals are observed in uterine endometrium (open arrows = surface luminal epithelium, solid arrowhead = uterine gland), clearly visible staining is localized in myometrium (A). In the utero-placental compartment during Agl.-induced parturition, placental COX2 is localized to the fetal trophoblast cells (solid arrows in B); there are only very weak signals in the uterine glands (solid arrowhead in C), but strong ones are present in myometrium (open arrowhead in $\mathbf{C}$ ). In the interplacental sites, following Agl. treatment, strong COX2 staining is localized in myometrium (open arrowhead in $\mathbf{E}$ ), and only very weak staining is present in surface (luminal) uterine epithelium (open arrows in $\mathbf{D}$ ) and uterine glands (solid arrowheads in D and $\mathbf{E}$ ). No or only very weak uterine signals are observed for PGFS/AKR1C3 preimplantation (F). Following implantation, PGFS/AKR1C3 protein is localized in surface (luminal) uterine epithelium and endometrial superficial glands (open and solid arrows in G). In the utero-placental compartment during Agl--induced parturition, placental PGFS/AKR1C3 protein is localized to the fetal trophoblast cells (solid arrows in $\mathbf{H}$ ); strong signals are localized also in the superficial endometrial glands, the so-called glandular chambers (open arrows in I). Within the interplacental uterine sites, in Agl.-treated animals, PGFS/AKR1C3 staining is localized predominantly in surface (luminal) uterine epithelium (open arrows in $\mathbf{J}$ ); the open and solid arrowheads in (K) indicate myometrium and uterine glands, respectively, with barely detectable signals.

EP4 (PTGER4) and HPGD was unaffected (P >0.05) (Figure 1D, Figure 2B, Figure 2F, Figure 3D).

Immunohistochemical (IHC) localization of gene expression All antibodies applied in this study were used in our previous projects and found to be specific for the canine species $[15,17,26]$. No or only very weak IHC signals were observed in the uterine endometrium for COX2 (PTGS2), whereas myometrium stained strongly in all samples investigated (Figure 4A). A similar signal distribution pattern was observed following the antigestagen treatment (Figure 4D,E). Additionally, utero-placental cross-sections (full thickness, middle part of the placental girdle avoiding marginal hematoma) obtained from the same animals in which abortion was induced with an antigestagen were included in the experiment and stained, revealing the COX2 (PTGS2) protein expression pattern previously described [15], i.e., strong COX2 signals were spread over the entire trophoblast during induced parturition coinciding with a substantial prepartum increase of PGF2 $\alpha$, while only weak signals were visible in the adjacent endometrial tissues (Figure 4B,C). After low and only barely detectable expression of PGFS/ AKR1C3 protein during the pre-implantation stage of pregnancy, its uterine expression was clearly detectable, displaying a tendency towards over-staining, post-implantation and was localized predominantly to the superficial luminal endometrial epithelium (Figure 4F,G), while only weak staining was observed in the uterine glands and in myometrium (not shown); distribution pattern and staining intensity did not change in Aglepristone ${ }^{\odot}$-treated dogs (Figure 4J,K). As for COX2 (PTGS2), the expression pattern of PGFS/AKR1C3 protein in the interplacental sites was comparable with its previously published [17] distribution in the utero-placental compartment, revealing the co-localization of PGFS/AKR1C3 with COX2 expression (Figure 4H,I).
The expression of PGES (Figure 5A-C) showed a similar distribution pattern from the pre-implantation until mid-gestation and at induced parturition-derived uterine samples, with signals localized in endometrial epithelial cells, weaker staining in the uterine stroma, and myometrial signals, which became clearly detectable at induced parturition (Figure 5C). A similar staining pattern was observed for the two PGE2-receptors, EP2 and EP4, with signals evenly distributed between the endometrial and myometrial compartments (Figure 5D-G). The expression of PGT (SLCO2A1) was co-localized with other PG-system members, however, with myometrial signals, appearing stronger following the antigestagen treatment (Figure 5H,I). A similar localization pattern, but with widely varying IHC signals among individual animals, was noted for HPGD (Figure 5J). As for EP2 and EP4, the signal distribution and intensity did not change during induced preterm parturition/abortion (Figure 5K,L).

\section{Discussion}

By showing strong functional interrelationships, and to some extent opposite effects, prostaglandins (PGs) unequivocally play an important role in regulating reproductive functions. Thus, whereas PGE2 was shown to be involved, e.g., in softening the cervix during parturition $[27,28]$, PGF $2 \alpha$ is the best-known luteolytic factor, while both PGs are involved in coordinating myometrial contractile activity [29-31]. Accordingly, uterine expression of the respective genes encoding for factors involved in PGs synthesis and metabolism, the so-called prostaglandin system, was shown in several species, such as cattle [22], sheep [32,33] and rats [34].

In the present study, the expression and localization of the PG-system was investigated in canine interplacental uterine tissues at selected time points of pregnancy, i.e., pre-implantation, post-implantation and mid-gestation (there was no tissue material available for experiments 

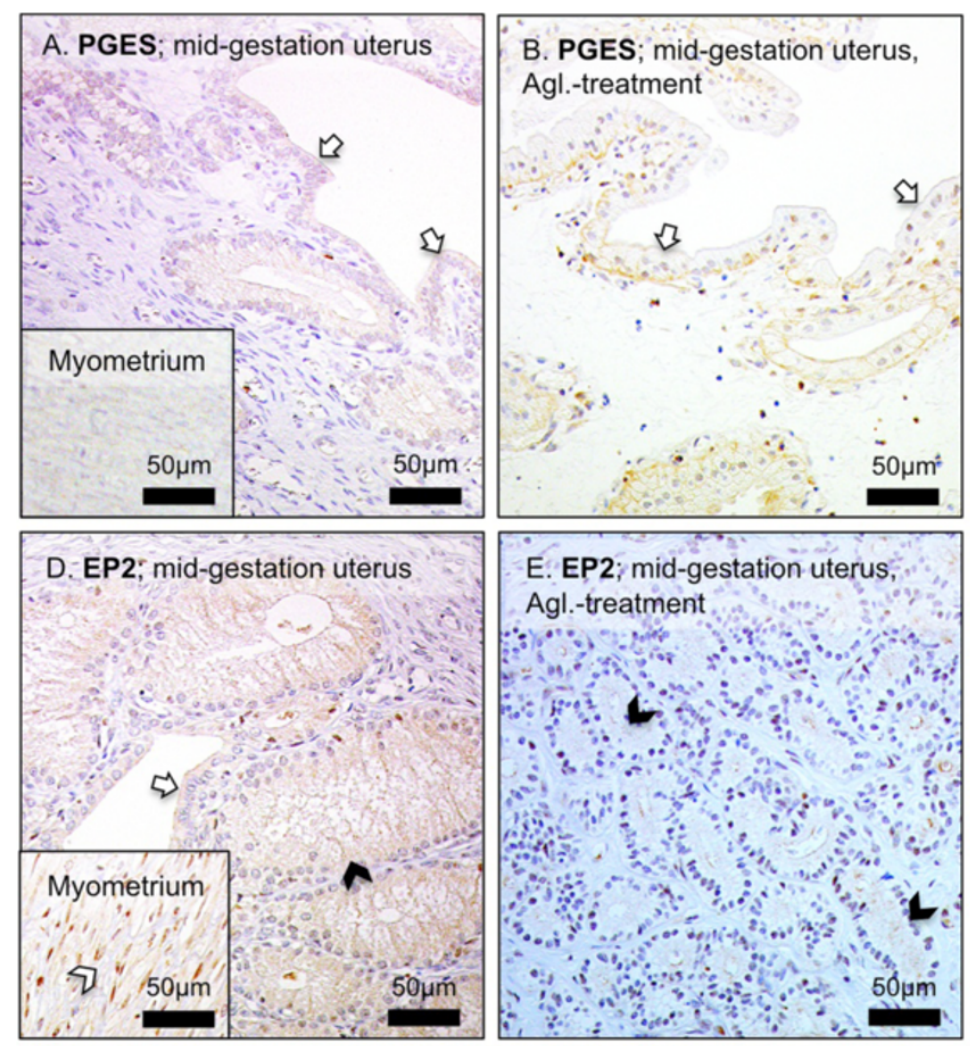
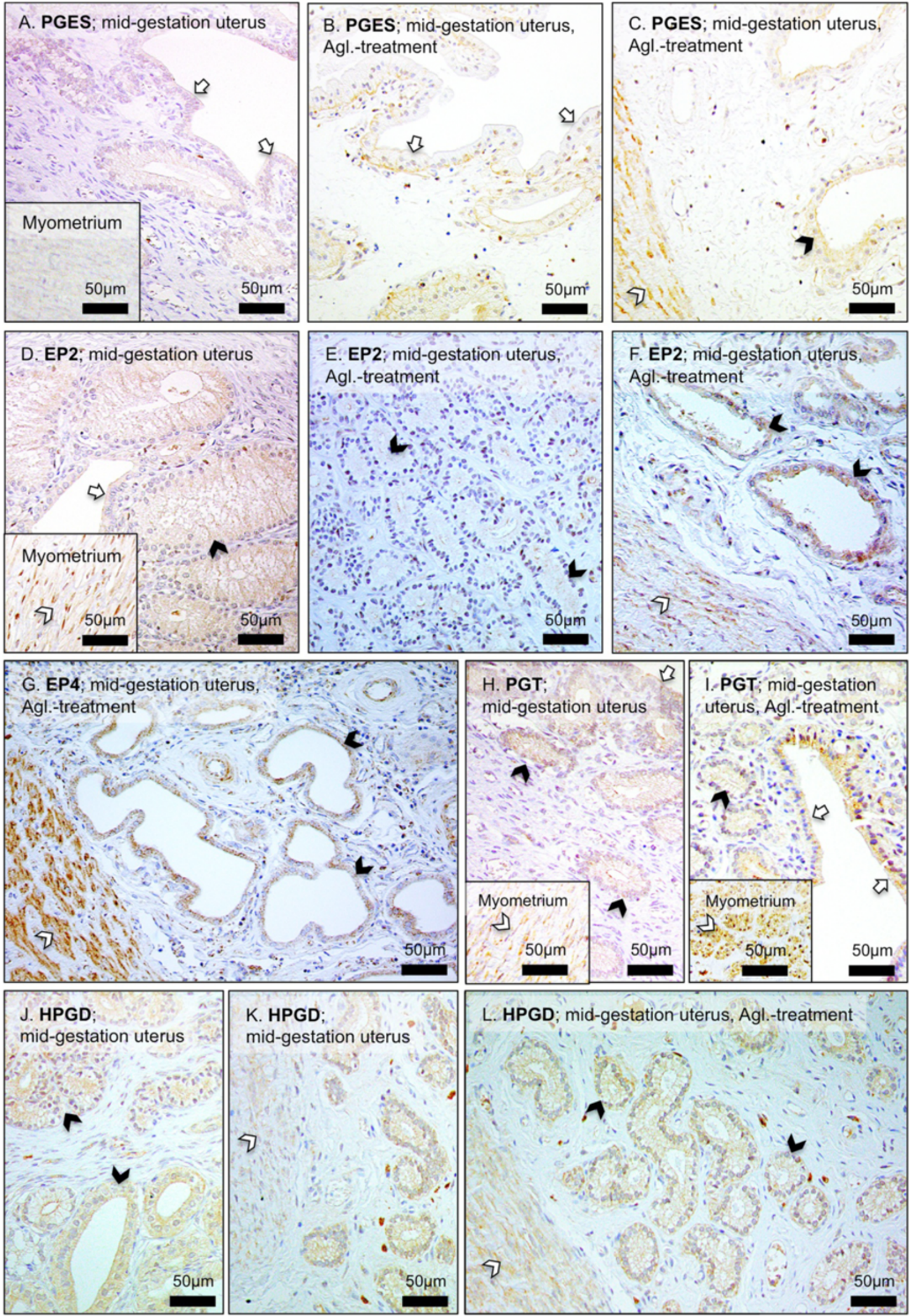

Figure 5 (See legend on next page.) 
(See figure on previous page.)

Figure 5 Immunohistochemical localization of prostaglandin E2 synthase (PGES), PGE2 receptors EP2 and EP4 (PTGER2 and PTGER4), prostaglandin transporter (PGT, SLCO2A1) and of 15-prostaglandin dehydrogenase (HPGD). Immunohistochemical (IHC) localization of: (A-C) PGES, and (D-F) EP2 (PTGER2) in interplacental uterine sites during mid-gestation and during Aglepristone ${ }^{\oplus}$ (Agl.)-induced abortion. (G) Representative picture of EP4 (PTGER4) expression in interplacental site during Aglepristone ${ }^{\circledast}$ (Agl.)-induced abortion in mid-gestation dog. $(\mathbf{H}, \mathbf{I})$ Expression of PGT (SLCO2A1) in interplacental uterine site during mid-gestation and during Aglepristone ${ }^{\oplus}$ (Agl.)-induced abortion. (J-L) Uterine expression of HPGD in interplacental uterine sites during mid-gestation and after Aglepristone ${ }^{\circledast}$ (Agl.) treatment. Open arrows = surface (luminal) uterine epithelium, solid arrowheads = uterine glands, open arrowheads in (C), (F), (K), (L) = myometrium.

from the interplacental sites from dogs during normal perpartum luteolysis).

Our data clearly indicate the basic capability of these tissues to synthesize and respond to prostaglandins, because the expression of all major components of the PG-system was detectable in all tissue samples investigated, both at the mRNA and protein level.

In general, the gene expression patterns observed resembled their expression in the corresponding uteroplacental compartments $[15,17]$. The expression of COX2 remained low until mid gestation, and the post-implantation period was characterized by increased PGFS/AKR1C3 expression. This, together with the gradually rising $P G E S$ expression levels and the concomitant presence of the respective prostaglandin receptors, imply a local role of these hormones during canine decidualization and implantation, as indicated previously $[15,17]$. Also, in agreement with our previous conclusion [17], a locally increased HPGD expression during earlier stages of pregnancy, which - in the present study - shows up as a tendency, could additionally restrict and coordinate the endocrine/paracrine effects of PGs.

The antigestagen-mediated blocking of the uterine PGR receptor, whose expression was significantly downregulated after implantation, resulted in upregulated uterine COX2 and PGES expression, thereby resembling their expression patterns in utero-placental compartments during normal and preterm parturition/abortion [15]. Interestingly, however, their localization patterns did not change significantly in response to the antigestagen treatment and, especially for COX2, the strongest signals were still observed in the myometrium. This was compared with their distribution pattern in the corresponding uteroplacental compartments, confirming their presence in the fetal part of the placenta, i.e., in the trophoblast cells, as described in our previous research [15,17]. Less dramatic changes, but also with an overall expression pattern resembling that observed in utero-placental samples, pertain to the uterine expression of PGFS/AKR1C3, FP, EP4 and $H P G D$ in antigestagen-treated bitches.

Consequently, based on our observations, we infer that the upregulated uterine expression of COX2 and PGES may originate mostly in the myometrial compartment, because their localization pattern did not differ significantly following treatment with Aglepristone ${ }^{\bullet}$. This is in contrast to observations made in cattle where the strongly upregulated COX2 expression was predominantly localized in surface epithelial cells, both in animals undergoing spontaneous labour and those in which it was induced prematurely $[22,35]$. However, as in cattle, in dogs PGs derived from the interplacental uterine sites seem to contribute primarily to myometrial contractility in conjunction with fetal expulsion, with the utero-placental compartment, however, remaining an important source of PGs around term [36,37].

The alterations in placental feto-maternal communication occurring in response to the local withdrawal of progesterone appear to be important for subsequently increasing output of the luteolytic hormone PGF $2 \alpha$, which with respect to the placenta must originate in the fetal component, i.e., in the trophoblast cells, where PGs synthesizing enzymes are expressed and localized. This conclusion seems to relate to both the bovine and canine species [15,36,37].

Furthermore, also in accordance with our previous studies [15], the upregulated expression of COX2 during induced parturition points towards the substantial role of COX2 (PTGS2) as a rate-limiting factor in provision of prepartum prostaglandins in the dog. Such a role of COX2 as a rate-limiting factor has also been observed in the horse [38], where blocking of endometrial COX2 expression by the conceptus at day 15 of early pregnancy prevented PGF2 $\alpha$-induced luteal regression and resulted in continuation of pregnancy.

At the functional level, our descriptive findings concerning the basal capability of canine uterine and placental tissues to produce and respond to PGs, are not conclusive and will require further studies including, e.g., measurements of the local PGs content within those tissues during different stages of canine gestation.

\section{Conclusions}

Our study presents the expression and localization patterns of factors involved in the synthesis of prostaglandins, the so-called prostaglandin-system, in canine interplacental uterine sites at selected times of pregnancy (pre-implantation, post-implantation and mid-gestation). Additionally, changes in the expression and availability of these factors and, hence, their potential contribution to the process of parturition, have been investigated in dogs 
in which progesterone receptor function was blocked by an antigestagen.

Based on the observations presented herein, in addition to prostaglandins of placental origin, the canine pregnant uterus also appears to be an organ actively involved in prostaglandin synthesis during canine parturition, most probably contributing predominantly to myometrial contractility. From a practical point of view, our findings can help us to better understand the mechanisms responsible for parturition in the dog, especially because decreased synthesis of prostaglandins and/or reduced uterine sensitivity to them could result in serious clinical conditions such as uterine inertia.

\section{Competing interests}

The authors declare that they have no competing interests.

\section{Authors' contributions}

MPK: Idea of the study, collecting tissue samples, Real Time PCR experiments, statistical evaluation, interpretation of data, manuscript writing. EK: RNA isolation, Real Time PCR experiments, immunohistochemical procedures. EH: Tissue preparation and processing, immunohistochemical procedures. BH: coordination of animal experiments and collection of tissue samples, knowledge transfer, critical discussion of the data, editing of the manuscript. $A B$ : knowledge transfer, critical discussion of the data, editing of the manuscript. All authors read and approved the final manuscript.

\section{Acknowledgements}

Supported by the Swiss National Science Foundation (SNSF) research grant number 408 31003A_140947. Authors are grateful to Dr. Barry Bavister for careful editing of the manuscript. The support of Virbac, France, in providing Aglepristone $^{\oplus}$ is highly appreciated.

\section{Author details}

1 Institute of Veterinary Anatomy, Vetsuisse Faculty, University of Zurich, Zurich, Switzerland. ${ }^{2}$ Clinic for Obstetrics, Gynecology and Andrology of Large and Small Animals, Justus-Liebig University Giessen, Giessen, Germany.

Received: 25 February 2014 Accepted: 8 May 2014

Published: 30 May 2014

\section{References}

1. Hoffmann B, Hoveler R, Nohr B, Hasan SH: Investigations on hormonal changes around parturition in the dog and the occurrence of pregnancy-specific non conjugated oestrogens. Exp Clin Endocrinol Diabetes 1994, 102:185-189.

2. Nishiyama T, Tsumagari S, Ito M, Kimura J, Watanabe G, Taya K, Takeishi M: Immunohistochemical study of steroidogenic enzymes in the ovary and placenta during pregnancy in the dog. Anat Histol Embryol 1999, 28:125-129.

3. Hoffmann B, Buesges F, Engel E, Kowalewski MP, Papa PC: Regulation of corpus luteum-function in the bitch. Reprod Domest Anim 2004, 39:232-240

4. Kowalewski MP: Luteal regression vs. prepartum luteolysis: Regulatory mechanisms governing canine corpus luteum function. Reprod Biol 2014 14(2):89-102. doi: 10.1016/j.repbio.2013.11.004.

5. Kowalewski MP: Endocrine and molecular control of luteal and placental function in dogs: a review. Reprod Domest Anim 2012, 47(Suppl 6):19-24.

6. Concannon PW, McCann JP, Temple M: Biology and endocrinology of ovulation, pregnancy and parturition in the dog. J Reprod Fertil Suppl 1989, 39:3-25

7. Concannon PW, Powers ME, Holder W, Hansel W: Pregnancy and parturition in the bitch. Biol Reprod 1977, 16:517-526.

8. Hoffmann B, Hoveler R, Hasan SH, Failing K: Ovarian and pituitary function in dogs after hysterectomy. J Reprod Fertil 1992, 96:837-845.
9. Olson PN, Bowen RA, Behrendt MD, Olson JD, Nett TM: Concentrations of progesterone and luteinizing hormone in the serum of diestrous bitches before and after hysterectomy. Am J Vet Res 1984, 45:149-153.

10. Kowalewski MP, Beceriklisoy HB, Aslan S, Agaoglu AR, Hoffmann B: Time related changes in luteal prostaglandin synthesis and steroidogenic capacity during pregnancy, normal and antiprogestin induced luteolysis in the bitch. Anim Reprod Sci 2009, 116:129-138.

11. Kowalewski MP, Fox B, Boos A, Reichler I: Prostaglandin E2 (PGE2) - the luteotropic factor of the gonadotropin-independent phase in the dog acts at the level of steroidogenic acute regulatory (STAR) protein. Reprod Dom Anim 2012, 47(Suppl. 2):32.

12. Kowalewski MP, Schuler G, Taubert A, Engel E, Hoffmann B: Expression of cyclooxygenase 1 and 2 in the canine corpus luteum during diestrus. Theriogenology 2006, 66:1423-1430.

13. Kowalewski MP, Fox B, Gram A, Boos A, Reichler I: Prostaglandin E2 functions as a luteotrophic factor in the dog. Reproduction 2013, 145:213-226.

14. Baan M, Taverne MA, de Gier J, Kooistra HS, Kindahl H, Dieleman SJ, Okkens AC: Hormonal changes in spontaneous and aglepristone-induced parturition in dogs. Theriogenology 2008, 69:399-407.

15. Kowalewski MP, Beceriklisoy HB, Pfarrer C, Aslan S, Kindahl H, Kucukaslan I, Hoffmann B: Canine placenta: a source of prepartal prostaglandins during normal and antiprogestin-induced parturition. Reproduction 2010, 139:655-664.

16. Nohr B, Hoffmann B, Steinetz BE: Investigation of the endocrine control of parturition in the dog by application of an antigestagen. J Reprod Fertil Supp/ 1993, 47:542-543.

17. Gram A, Buchler U, Boos A, Hoffmann B, Kowalewski MP: Biosynthesis and Degradation of Canine Placental Prostaglandins: Prepartum Changes in Expression and Function of Prostaglandin F2alpha-Synthase (PGFS, AKR1C3) and 15-Hydroxyprostaglandin Dehydrogenase (HPGD). Biol Reprod 2013, 89:2.

18. Kowalewski MP, Meyer A, Hoffmann B, Aslan S, Boos A: Expression and functional implications of Peroxisome Proliferator-Activated Receptor Gamma (PPARgamma) in canine reproductive tissues during normal pregnancy and parturition and at antiprogestin induced abortion. Theriogenology 2011, 75:877-886.

19. Kowalewski MP, Michel E, Gram A, Boos A, Guscetti F, Hoffmann B, Aslan S, Reichler I: Luteal and placental function in the bitch: spatio-temporal changes in prolactin receptor (PRLr) expression at dioestrus, pregnancy and normal and induced parturition. Reprod Biol Endocrinol 2011, 9:109.

20. Luz MR, Bertan CM, Binelli M, Lopes MD: In vitro PGF2a production by endometrium and corpus luteum explants from pregnant and nonpregnant diestrus bitches and placental explants from pregnant bitches. Theriogenology 2006, 66:1442-1447.

21. Concannon PW, Butler WR, Hansel W, Knight PJ, Hamilton JM: Parturition and lactation in the bitch: serum progesterone, cortisol and prolactin. Biol Reprod 1978, 19:1113-1118.

22. Wehbrink D, Hassig M, Ritter N, Zerbe H, Bleul U, Boos A: Immunohistochemical demonstration of cyclooxygenase-2 (COX-2) and prostaglandin receptors EP2 and FP expression in the bovine intercaruncular uterine wall around term. Anim Reprod Sci 2008, 106:241-254.

23. Amoroso EC: Placentation. In Marshall's physiology of reproduction. Edited by Parkes AS. London: Longmans Green; 1952:127-316.

24. Kehrer $A$ : Zur entwicklung und ausbildung des chorions der placenta zonaria bei katze, hund und fuchs. Zeitschrift fur Anatomie und Entwicklungsgeschichte 1973, 143:25-42.

25. Kowalewski MP, Mason JI, Howie AF, Morley SD, Schuler G, Hoffmann B: Characterization of the canine 3beta-hydroxysteroid dehydrogenase and its expression in the corpus luteum during diestrus. J Steroid Biochem Mol Biol 2006, 101:254-262.

26. Kautz E, Gram A, Aslan S, Ay SS, Selçuk M, Kanca H, Koldaş E, Akal E, Karakaş K, Findik M, Boos A, Kowalewski MP: Expression of genes involved in the embryo-maternal interaction in the early pregnant canine uterus. Reproduction 2014, 147(5):703-717.

27. Stys SJ, Dresser BL, Otte TE, Clark KE: Effect of prostaglandin E2 on cervical compliance in pregnant ewes. Am J Obstet Gynecol 1981, 140:415-419.

28. Fuchs AR, Goeschen K, Rasmussen AB, Rehnstrom JV: Cervical ripening and plasma prostaglandin levels. Comparison of endocervical and extra-amniotic PGE2. Prostaglandins 1984, 28:217-227.

29. Senior J, Marshall K, Sangha R, Clayton JK: In vitro characterization of prostanoid receptors on human myometrium at term pregnancy. Br J Pharmacol 1993, 108:501-506. 
30. Senior J, Sangha R, Baxter GS, Marshall K, Clayton JK: In vitro characterization of prostanoid FP-, DP-, IP- and TP-receptors on the non-pregnant human myometrium. Br J Pharmacol 1992, 107:215-221.

31. Senior J, Marshall K, Sangha R, Baxter GS, Clayton JK: In vitro characterization of prostanoid EP-receptors in the non-pregnant human myometrium. Br J Pharmacol 1991, 102:747-753.

32. Wu WX, Ma XH, Yoshizato T, Shinozuka N, Nathanielsz PW: Increase in prostaglandin $\mathrm{H}$ synthase 2 , but not prostaglandin F2alpha synthase mRNA in intrauterine tissues during betamethasone-induced premature labor and spontaneous term labor in sheep. J Soc Gynecol Investig 2001, 8:69-76.

33. Gyomorey S, Gupta S, Lye SJ, Gibb W, Labrie F, Challis JR: Temporal expression of prostaglandin $\mathrm{H}$ synthase type 2 (PGHS-2) and P450(C17) in ovine placentomes with the natural onset of labour. Placenta 2000, 21:478-486.

34. Satoh $H$, Watanabe $K$, Kawaminami M, Kurusu S: A comprehensive immunohistochemistry of prostaglandins F2alpha and E2 synthetic enzymes in rat ovary and uterus around parturition. Prostaglandins Other Lipid Mediat 2013, 106:23-28.

35. Fuchs AR, Rust W, Fields MJ: Accumulation of cyclooxygenase-2 gene transcripts in uterine tissues of pregnant and parturient cows: stimulation by oxytocin. Biol Reprod 1999, 60:341-348.

36. Arosh JA, Banu SK, Chapdelaine P, Fortier MA: Temporal and tissue-specific expression of prostaglandin receptors EP2, EP3, EP4, FP, and cyclooxygenases 1 and 2 in uterus and fetal membranes during bovine pregnancy. Endocrinology 2004, 145:407-417.

37. Schuler G, Teichmann U, Kowalewski MP, Hoffmann B, Madore E, Fortier MA, Klisch K: Expression of cyclooxygenase-II (COX-II) and 20alpha-hydroxysteroid dehydrogenase (20alpha-HSD)/prostaglandin F-synthase (PGFS) in bovine placentomes: implications for the initiation of parturition in cattle. Placenta 2006, 27:1022-1029.

38. Boerboom D, Brown KA, Vaillancourt D, Poitras P, Goff AK, Watanabe K, Dore $M$, Sirois J: Expression of key prostaglandin synthases in equine endometrium during late diestrus and early pregnancy. Biol Reprod 2004, 70:391-399.

doi:10.1186/1477-7827-12-46

Cite this article as: Kowalewski et al:: Interplacental uterine expression of genes involved in prostaglandin synthesis during canine pregnancy and at induced prepartum luteolysis/abortion. Reproductive Biology and Endocrinology 2014 12:46.

\section{Submit your next manuscript to BioMed Central and take full advantage of:}

- Convenient online submission

- Thorough peer review

- No space constraints or color figure charges

- Immediate publication on acceptance

- Inclusion in PubMed, CAS, Scopus and Google Scholar

- Research which is freely available for redistribution 